Document downloaded from:

http://hdl.handle.net/10251/156865

This paper must be cited as:

Carceller-Carceller, JM.; Martínez Galán, JP.; Monti, R.; Bassan, JC.; Filice, M.; Iborra Chornet, S.; Yu, J.... (2019). Selective synthesis of citrus flavonoids prunin and naringenin using heterogeneized biocatalyst on graphene oxide. Green Chemistry. 21(4):839-849. https://doi.org/10.1039/c8gc03661f

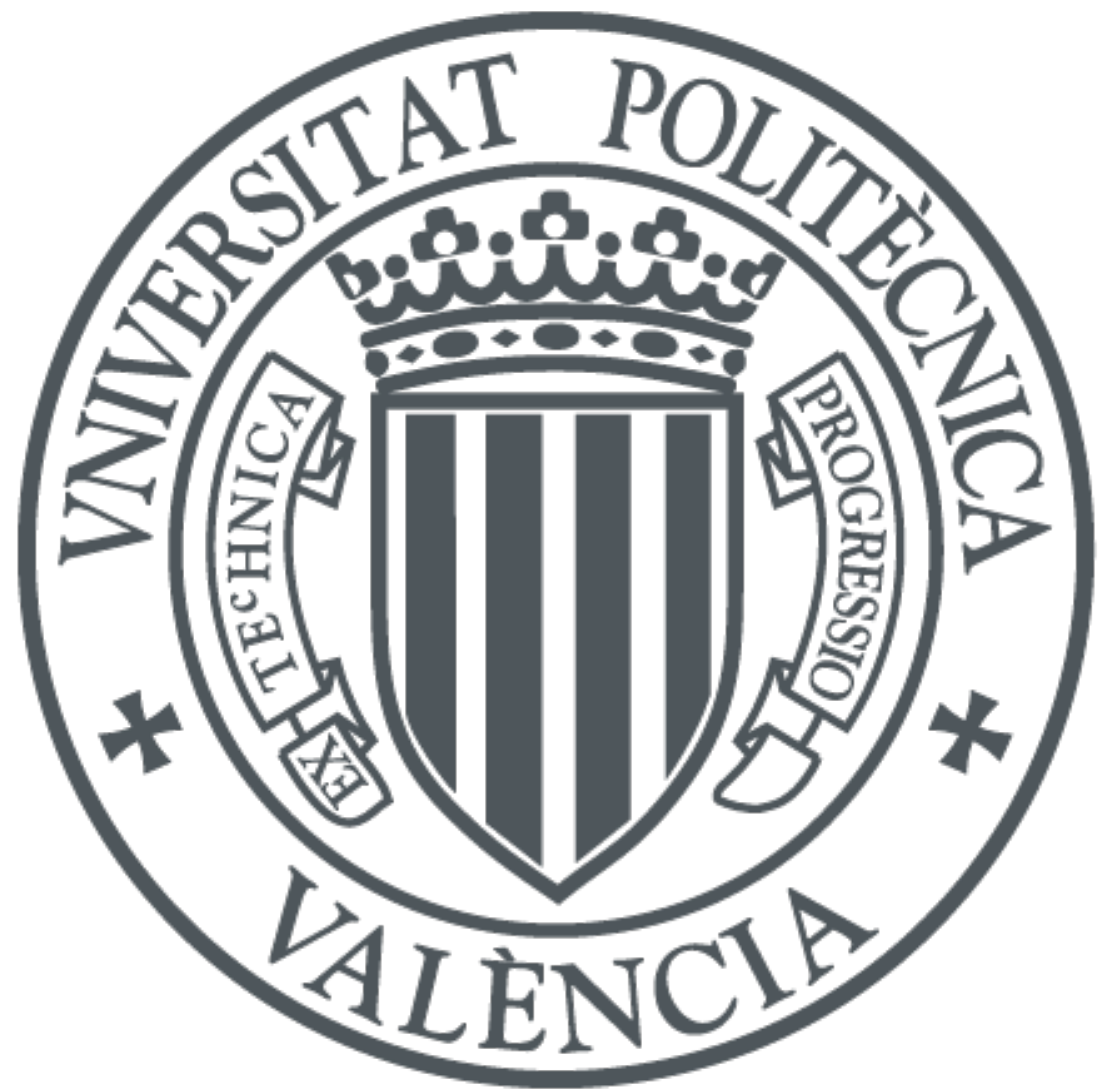

The final publication is available at

https://doi.org/10.1039/c8gc03661f

Copyright The Royal Society of Chemistry

Additional Information 


\title{
Selective synthesis of citrus flavonoids prunin and naringenin using heterogeneized biocatalyst on graphene oxide
}

\author{
Jose Miguel Carceller ${ }^{d}$, Julián Paul Martínez Galán ${ }^{a}$, Rubens Monti ${ }^{b}$, Juliana Cristina \\ Bassan $^{b}$, Marco Filice $^{b, c}$, Sara Iborra*d, Jihong Yu ${ }^{e}$, Avelino Corma*d
}

${ }^{a}$ School of Nutrition and Dietetic, University of Antioquia CP 050010, Medellín, Antioquia, Colombia.

${ }^{b}$ Department of Food and Nutrition, Faculdade de Ciências Farmacêuticas, UNESP Univ Estadual Paulista.CEP 14801-902, Araraquara, SP, Brazil

${ }^{c}$ Department of Biocatalysis Institute of Catalysis (ICP-CSIC) Marie Curie 2 Cantoblanco Campus UAM 28049 Madrid Spain

d Universitat Politécnica de Valencia, Institute of Chemical Technology (ITQ) - Valencia, Spain, Avenida Los Naranjos s/n 46022

eState key Laboratory of Inorganic Synthesis \& Preparative Chemistry Jilin University, 2699 Qianjin Street Changchun 130012, P.R. China

Keywords: supported naringinase, graphene oxide, naringin, prunin, naringenin

\section{Abstract}

The production of citrus flavonoids prunin and naringenin has been performed selectively through the enzyme hydrolysis of naringin, a flavonoid glycoside abundant in grapefruit wastes. To produce the monoglycoside flavonoid, prunin, the crude naringinase from Penicillium decumbens has been purified by a single purification step resulting in one enzyme with high $\alpha$-rhamnosidase activity. Both, crude and purified enzymes have been covalently immobilized on graphene oxide. The activity of the 
immobilized enzymes at different $\mathrm{pH}$ and temperatures as well as the thermal stability were determined and compared with those exhibited by the free naringinases using specific substrates: $p$-nitrophenyl- $\beta$-D-glucoside (Glc-pNP) and p-nitrophenyl-alpha-Lrhamnopyranoside (Rha-pNP). The crude and purified naringinase supported on GO were tested in the hydrolysis of naringin giving naringenin and prunin respectively in excellent yields. The supported enzymes can be reused many times without loss of activity. The naringinase stabilized on GO, has high potential to produce the valuable citrus flavonoids prunin and naringenin .

\section{Introduction}

Glycosylated flavonoids are important constituent of citrus with important beneficial effects on human health. ${ }^{1}$ Naringin $\left(4^{\prime},-5,7^{\prime}\right.$-trihydroxyflavanone-7-rhamnoglucoside) is a glycosylated flavonoid highly present in grapefruits which can be easily extracted from peel, membrane and seed wastes. ${ }^{2}$ Moreover, naringin is one of the main bittering components of the grapefruit juices and when hydrolyzed releases non-bitter products as aglycone and monosaccharides. The hydrolysis products, the monoglycoside flavonoid, prunin (4',5,7-trihydroxyflavanone- $\beta$-D-glucoside), and the aglycone naringenin (4',5,7-trihydroxyflavanone) are important compounds with a large potential in the pharmaceutical, cosmetic and food industries due to a wide range of biological activities such as antioxidant, anti-inflammatory, antiulcer, anticancer, antiviral and neuroprotective activity. ${ }^{3,4}$ The preparation of naringenin and particularly monoglycoside flavonoids such as prunin by conventional chemical methods is difficult and usually produces side reactions leading to low selectivity to the 
target compound. Therefore, the use of enzyme methods is advantageous due to their high selectivity and mild reaction conditions.

Naringinase is an enzyme complex consisting of $\alpha$-L-rhamnosidase (EC 3.2.1.40) and flavonoid- $\beta$-glucosidase activities (EC 3.2.1.21). This enzyme has many important applications in the food and pharmaceutical industries because of its ability to hydrolyze many glycosides, e.g., 6-O- $\alpha$-L-rhamnopyranosyl- $\beta$-D-glucopyranosides, naringin, hesperidin, and rutin. ${ }^{5,6}$

Naringinase catalyzes the hydrolysis of the flavonoid naringin to rhamnose, glucose and naringenin, through two-step process. The first reaction converts the $\alpha$-Lrhamnosidase-catalyzed enzyme hydrolysis of naringin to rhamnose and prunin. The latter is further hydrolized by the $\beta$-D-glucosidase into glucose and the flavanone naringenin. ${ }^{5}$ (Scheme 1$)$.

The multireaction-multienzymatic approach can be highly interesting from a process intensification point of view, and it has been applied to biotransformations of antibiotics and steroids ${ }^{7}$ and in debittering of citrus fruit juices. ${ }^{8}$

For large scale applications such as in industrial biocatalysis, immobilized enzymes have several advantages respect to the free enzyme such as high thermal stability, easy separation from the reaction media, and particularly the possibility to reuse the biocatalyst. Due to their industrial interest, naringinase has been supported on a variety of materials such as tannin-aminohexylcellulose, ${ }^{9}$ chitin, ${ }^{10}$ cellulose acetate films, ${ }^{11}$ glutaraldehyde coated wood chips ${ }^{12}$ and MCM-41, ${ }^{13}$ over sol-gel of polyvinyl alcohol (PVA), ${ }^{14,15}$ entrapped with sodium or potassium alginate ${ }^{16-18}$ and recently immobilized over graphene. ${ }^{19}$ 
Graphene oxide (GO), a material with high surface area and a structure based on individual nano sheets containing carbonyl, carboxyl, hydroxyl and epoxy groups that confer a good dispersibility in water, has attracted recently much interests as support for enzyme immobilization. ${ }^{20-26} \mathrm{GO}$ is commercially available at low price, however its production is mainly based on the oxidation of graphite using an excess of permanganate together with sodium nitrate and concentrated sulphuric acid, that are not green methodologies. Therefore, the use of greener technologies to produce GO are highly desirable. ${ }^{27}$

The use of immobilized enzymes in the food and pharmaceutical industries requires a ready available support containing reactive groups that allow easy and low cost immobilization procedures. The physicochemical characteristics of $\mathrm{GO}$ along with their scalable manufacture prompted us to study the possibility to use GO as carrier of naringinase and their potential industrial applications. As far as we know, this material has not been used to immobilize the enzyme naringinase.

Regardless of increasing demand for citrus flavonoids with well recognized health benefits, lack of well-defined environmentally friendly production methods have precluded commercial progress in this market. Therefore, improved methods for their production are of interests in the pharmaceutical and food industries. Here, we present the valorization of naringin (that can be extracted from grapefruit wastes) into prunin and naringenin through an environmentally friendly method.

However, it is interesting to point out that to produce prunin in high yield from naringin using naringinase (first step in Scheme 1 ), the $\beta$-D-glucosidase activity of the enzyme has to be suppressed. This can be achieved by selective inactivation of the 
protein fraction with $\beta$-D-glucosidase activity ${ }^{28}$ or by using a purified protein fraction with $\alpha$-L-rhamnosidase activity, that usually requires expensive purification methods. 29 In this work, to produce selectively the monoglycoside flavonoid prunin and rhamnose (a valuable sugar in food industry), we have purified the commercial naringinase by a simple method obtaining a purified enzyme with high $\alpha$-rhamnosidase activity, which allows obtaining prunin in high yield from naringin. We have immobilized on GO a crude naringinase from Penicillium decumbens as well as a purified naringinase with high $\alpha$-rhamnosidase activity. The enzyme properties of both immobilized enzymes (crude and pure) have been systematically studied and compared with those of the free enzymes using substrates specific for each enzymatic activity: p-nitrophenyl-alpha-L-rhamnopyranoside (Rha-pNP) and p-nitrophenyl- $\beta$-Dglucoside (Glc-pNP) (Scheme $2 a$ and $2 b$ ). Finally, the crude and purified enzymes supported on GO were used in the hydrolysis of naringin to produce naringenin and prunin respectively in high yields and selectivities.

\section{Results and discussion}

\section{Purification of crude naringinase}

The most general method to purify naringinase is through the two steps column cromatography. This methodology involves a first chromatography of the crude enzyme using an ion exchange chromatography column that is eluted with a linear gradient concentration of salts (usually $\mathrm{NaCl}$ ). Then, the fractions with enzyme activity are collected, dialyzed and purified further with a gel permeation column chromatography (size exclusion chromatography). ${ }^{30-35}$ The main disadvantages of this 
methodology are the long time consuming and in most cases the loss of activity of the purified rhamnosidase.

In this work the crude naringinase has been purified by a single purification step using ion exchange chromatography by the batch technique, as described in the experimental section. A desorption study using a gradient of $\mathrm{NaCl}$ has been done (Supporting information. Figure S1). The resin was washed with diffent concentrations of $\mathrm{NaCl}(25-1000 \mathrm{mM})$ and the linked protein was desorbed in this process, latter the protein was dialyzed and the $\alpha$-rhamnosidase and $\beta$-glucosidase activities were tested. The $\alpha$-L-rhamnosidase enzyme was selectively desorbed with $50 \mathrm{mM} \mathrm{NaCl}$. The obtained protein fraction was lyophilized and analyzed by SDS-PAGE analysis (Figure 1) retrieving a quite pure protein with molecular weight $\sim 66 \mathrm{kDa}$ in agreement with the molecular weight reported in the literature. ${ }^{29}$

The $\alpha$-L-rhamnosidase and $\beta$-D-glucosidase activities of the purified enzyme were determined using the specific substrates $p$-nitrophenyl- $\beta$-D-glucoside (Glc-pNP) and pnitrophenyl-alpha-L-rhamnopyranoside (Rha-pNP) and compared with those exhibited by the crude enzyme (Table 1 ). As reported ${ }^{36}$, the crude naringinase before and after dialysis presents similar glucosidase and rhamnosidase activity. On the other hand, the purified enzyme exhibits considerably higher rhamnosidase activity being approximately two fold higher than the crude one. These results show that through a simple purification method it is possible to obtain a purified enzyme fraction with high rhamnosidase activity.

Immobilization of naringinase on GO 
Previously to the immobilization of the enzyme, the support GO was characterized by elemental and FTIR analysis. The elemental analysis showed that the support is highly oxygenated (see Table S1), while in Figure 2 stretching vibration bands of GO corresponding to $-\mathrm{OH}\left(3370 \mathrm{~cm}^{-1}\right),-\mathrm{C}=\mathrm{O}\left(1725 \mathrm{~cm}^{-1}\right)$ and $-\mathrm{C}-\mathrm{O}\left(1360 \mathrm{~cm}^{-1}\right)$ groups are observed along with a band associated to $\mathrm{C}=\mathrm{C}$ of aromatic rings $\left(1575 \mathrm{~cm}^{-1}\right)$. Furthermore, the presence of the epoxy groups is confirmed by the characteristic bands at $1230 \mathrm{~cm}^{-1}, 1056 \mathrm{~cm}^{-1}$, and $845 \mathrm{~cm}^{-1}$ associated with the symmetric and asymmetric stretching and deformation vibrations, respectively. These results indicate the existence of oxygen-containing functional groups on the GO nanosheets, at least acids and epoxides, through which the enzyme could be covalently immobilized. In Figure 3 a structure model of $\mathrm{GO}$ is presented that shows the different functional groups. Moreover, the morphology of the as-synthesized GO was characterized by TEM and AFM imaging. The TEM image (Figure 4B) confirmed the nanosheets structure of GO, while the cross-sectional view of the AFM indicates that the thickness of GO was comprised between 0.6 and $1.1 \mathrm{~nm}$ (Fig 4A and 4C).

The immobilization of crude Naringinase on GO was performed by incubating the enzyme solution with $\mathrm{GO}$ in phosphate buffer at $\mathrm{pH}=7$ (see experimental section). To determine the amount of enzyme immobilized, the supernatant was removed and the solid was washed until not protein was observed. Then the amount of nonimmobilized protein in the supernatant was determined by the bicinchoninic acid test. 37 Results showed that after 3 and $24 \mathrm{~h}$, the amount of enzyme immobilized yield was $66 \%$ and $100 \%$ respectively (Table S2), corresponding to a $40 \mathrm{mg} / \mathrm{g}$ and $60 \mathrm{mg} / \mathrm{g}$ of enzyme respectively. 
The immobilized enzyme (crude) Ngsa/GO (60 mg/g) could be clearly observed by AFM imaging. In Figure 5A bright spots on the GO surface corresponding to the deposited enzyme can be observed. Additionally, TEM images of Ngsa/GO showed that the structure of the graphene oxide is retained after the immobilization process (Fig 5B). Moreover, the cross-sectional view of the AFM indicates that the thickness of the $\mathrm{Ngsa} / \mathrm{GO}(\sim 3-5.5 \mathrm{~nm})$ (Figure $5 \mathrm{C})$ is substantially higher than of the GO ( 0.6-1.1 $\mathrm{nm}$ ) (Figure 4C), confirming the immobilization of Naringinase on the surface of GO. The minimum radius of proteins can be estimated theoretically from the molecular weight. ${ }^{38}$

According to the SDS-PAGE analysis (Figure 1) the crude naringinase is a complex enzyme with a molecular weight in the range of 33 to $97 \mathrm{KDa}$. From these values the minimum radius from 2.12 to $3.03 \mathrm{~nm}$ can be estimated, which agree with the thickness determined by AFM.

It has been reported that the enzyme immobilization onto $\mathrm{GO}$ or reduced $\mathrm{GO}$ might be a results of different interactions, including electrostatic, hydrophobic and $\pi-\pi$ stacking interactions. ${ }^{20}$ However the presence of reactive oxygen functional groups on the GO gives also the possibility to form covalent bonds, presumably between nucleophylic groups of the enzyme and the functional groups of the GO such as carbonyl, carboxyl and epoxy groups. However, it has been reported that this covalent interaction of enzymes with GO usually occurs at a slowly reaction rate. ${ }^{39}$ Then, depending on the reaction conditions, it is reasonable to assume that after $24 \mathrm{~h}$ of incubation, a high proportion of enzyme was mainly covalently bonded to GO. In fact, electrostatic interactions can be ruled out due to fact that the isoelectronic point of 
naringinase is at $\mathrm{pH}$ of $\sim 5$. That means that it has a net positive charge at $\mathrm{pH}$ below of 5 and a net negative charge at $\mathrm{pH}$ above 5 . The measurement of the zeta potential of the $\mathrm{GO}$ indicates that the sheets are negatively charged at $\mathrm{pH}=7$. This result agrees with those reported by Zhang et al. who found that GO sheets are negatively charged in aqueous solutions with a $\mathrm{pH}$ range between 4 and $11 .{ }^{39}$ Therefore electrostatic interactions between enzyme and GO are not expected to occur at the immobilization $\mathrm{pH}(\mathrm{pH}=7)$. However, to discard an electrostatic interaction the immobilization process was additionally performed at $\mathrm{pH} 4.5$ and 10, and after verifying that in all cases the enzyme immobilization was $100 \%$, the biocatalyst (crude naringinase on GO) was incubated in a solution with increasing concentration of sodium chloride. Hence, $50 \mathrm{mg}$ of the immobilized biocatalyst were added into a solution of $\mathrm{NaCl} 0.5 \mathrm{M}$ during 2 hours, after that it was centrifuged and the released protein concentration was analyzed by bicinchoninic acid test. The same methodology was done using a solution of $\mathrm{NaCl} 1 \mathrm{M}$. When the immobilization is performed below $\mathrm{pH} 5$ some enzyme desorption occur (see Table S3), indicating in this case the electrostatic interaction contribution to the enzyme immobilization. However, at $\mathrm{pH} 7$ and 10, protein desorption is not observed, indicating that the type of interaction between enzyme and support could be mainly covalent.

\section{Effect of the pH on enzyme activity}

The enzyme activity of the immobilized naringinase (crude and pure) in function of the $\mathrm{pH}$ was measured on the hydrolysis of Rha-pNP in a $\mathrm{pH}$ range from 3.0 to 8.0. As can be observed in Figure 6 the optimum $\mathrm{pH}$ (4.5) for the immobilized enzyme was the same as for the free enzyme, indicating that the support does not modify the proton 
distribution between the aqueous phase and the microenviroment surrounding the active site of the enzyme. ${ }^{9,15}$

It is interesting to notice that the capacity of the immobilized naringinase to operate with high activity occurs at $\mathrm{pH}$ levels similar to the fruit juices (below 5). Being this highly desirable for large scale applications in fruit juices processing.

\section{Influence of the temperature on the reaction rate}

The rhamnosidase activity as a function of the temperature for the crude and pure enzyme in their free or immobilized form was assessed. The optimum temperature for the crude enzyme in the free and immobilized form was between $70-75^{\circ} \mathrm{C}$, while the optimum temperature for the purified enzyme in the free and immobilized form was between $60-65{ }^{\circ} \mathrm{C}$ (Figure 7). The balance between the effect of the temperature on the rate of the enzyme reaction and the rate of the enzyme degradation determines the optimum temperature of operation. ${ }^{40}$ Therefore, the results indicate that the crude enzyme is slightly more stable than the pure enzyme, and both immobilized enzymes on the GO present similar activity with temperature. Moreover, the activity of the immobilized enzymes was less affected by the temperature indicating that the immobilization stabilizes the structure of the enzyme against denaturation.

\section{Determination of Michaelis Menten constant $\left(\mathrm{K}_{\mathrm{M}}\right)$}

The effect of substrate concentration on naringinase activity (crude and pure) in free and immobilized forms was determined by measuring the reaction rates at substrate concentrations of Rha-pNP ranging from $0.006-0.312 \mathrm{mM}$ while keeping the reaction time constant $(10 \mathrm{~min})$. The Michaelis constants $\left(\mathrm{K}_{\mathrm{M}}\right)$ were determined by the 
Lineweaver-Burk plots (Figure S2). The $\mathrm{K}_{M}$ constanst for the free crude and pure naringinase were 1.87 and 1.80 respectively. These results are similar to those reported by Romero et al. ${ }^{41}$, who found a $\mathrm{K}_{\mathrm{M}}$ value of 1.52 using the same substrate ( $p$-nitrophenyl-alpha-L-rhamnopyranoside). Considerably lower $K_{M}$ values of 0.80 and 0.61 were found for the GO immobilized crude and pure naringinase respectively (See Figure $\mathrm{S} 2 \mathrm{~A}$ and $\mathrm{S} 2 \mathrm{~B}$ ) indicating a higher affinity for the substrate when the enzyme is immobilized on GO. These results were consistent with previous results reported on immobilized naringinase. ${ }^{11-13}$

In Table 2 the $K_{M}$ obtained values of free and immobilized naringinase over different supports and for different substrates are summarized. For comparison purposes the $\mathrm{CK}_{M}$ ratios (which is the $\mathrm{K}_{M}$ of the free enzyme divided by the $\mathrm{K}_{M}$ of the immobilized naringinase) for the different biocatalysts are included. As can be observed, the $\mathrm{CK}_{\mathrm{M}}$ value found in this work is among the highest previously reported, showing the advantages of the immobilization of naringinase on GO.

\section{Thermal stability of free and immobilized enzymes}

Free and immobilized naringinase were exposed separately to increasing temperatures between 30 and $100{ }^{\circ} \mathrm{C}$ for $1 \mathrm{~h}$. After that, the Rha-pNP substrate was added and the assay to determine the residual catalytic activity was carried out. As can be observed in Figure 8 the activity of free and immobilized enzymes remains constant until $70{ }^{\circ} \mathrm{C}$. Nevertheless, at higher temperatures the activity of enzymes immobilized on GO is considerably higher than free enzymes. When subjected to $85^{\circ} \mathrm{C}$, the immobilized enzymes retained their enzyme activity above $80 \%$. However, the free enzyme only retains $40 \%$. These results indicate that the immobilization generated a considerable 
increase in the thermal stability of the enzyme. Apparently the immobilization of naringinase on GO generates a better stabilization against heat denaturation of the catalyst in comparison to the free naringinase. This fact is important for industrial applications because the higher stability of the immobilized enzyme will be reflected on the operational stability.

\section{Production of prunin and naringenin and study of biocatalysts stability}

One important advantage of the immobilized enzyme is not only that can be easily separated from the reaction media but also that it allows continuous operation. These features significantly can decrease the cost of the process under practical applications.

To produce prunin and naringenin and to test the stability and recyclability of GO immobilized naringinase, we used naringin as substrate and their hydrolysis using crude and pure immobilized naringinase was performed as described in the experimental section. First, the activity recovery of the biocatalysts was determined by comparing the activity of the amount of free enzyme used, with the activity of the total amount of immobilized enzyme. The results showed that the activity recovery of the immobilized crude and pure naringinase on GO was 86 and $91 \%$ respectively, indicating that the activity of both immobilized enzymes with respect of the free enzyme is high. Then, several cycles were performed to stablish the long-term stability of the immobilized enzymes. Thus, after the first cycle, the reaction mixture was centrifuged to remove the supernatant and the immobilized naringinase was repeatedly washed and the activity was essayed again. The catalytic cycles versus enzyme activities for the pure and crude immobilized naringinase are presented in Figures 9 and 10 respectively. 
As can be observed the conversion of naringin as well as the selectivity to prunin (Figure 9) or naringenin (Figure 10) is maintained during 10 consecutive cycles, indicating the high stability of the immobilized enzyme. In terms of production capacity of prunin and naringenin after ten cycles, $34.61 \mathrm{mg}$ of prunin/mg of pure enzyme and $14.43 \mathrm{mg}$ of naringenin/mg of crude enzyme could be obtained. The catalytic cycles of the pure naringinase were continued and after 25 cycles, $86.54 \mathrm{mg}$ of prunin $/ \mathrm{mg}$ of pure enzyme were obtained.

The long term stability as well as the productivity (TON), defined as the mg of naringin hydrolyzed per mg of enzyme, of the immobilized pure and crude naringinase on GO are compared with those previously reported in literature using naringinase immobilized on different supports (see Table S4). As can be observed most of them are not stable and the ones claimed stable give lower TON showing our catalyst a productivity several times superior to the previously reported. This of special relevance from the point of wiew of the large scale production of the high value prunin and naringenin through a green and economically viable method. In a first approximation, the economical balance based on the long term stability and TON indicates that the cost of prunin and naringenin associated to the cost of enzyme and GO would be around $235 € / \mathrm{Kg}$, which is several times lower than the price of prunin or naringenin in the market. Therefore, this can be a competitive method for producing these flavonoids.

Finally, for comparison purposes, the naringinase (crude) was also immobilized onto reduced graphene oxide (RGO), which contains a relatively lower amount of oxygenated functions than GO (see Table S1 and Figure 2). The immobilization on 
reduced graphene (RGO) was performed under the same conditions that in presence of GO during $24 \mathrm{~h}$. After this time, the amount of immobilized naringinase (Ngsa/RGO(24 h)) was only $65 \%$ (similar to those obtained with GO after $3 \mathrm{~h}$, see Table S2). The catalytic activity of $\mathrm{Ngsa} / \mathrm{RGO}(24 \mathrm{~h})$ for the hydrolysis of naringin after various catalytic cycles was investigated and compared with those obtained with $\mathrm{Ngsa} / \mathrm{GO}(3 \mathrm{~h})$. In Figure 11 can be observed that for the both derivatives, the catalytic activity is maintained during three catalytic cycles, indicating the strong immobilization of naringinase on both supports ( $G O$ and $R G O)$. However, it is interesting to notice that when the activity of $\mathrm{Ngsa} / \mathrm{GO}(3 \mathrm{~h})$ and $\mathrm{Ngsa} / \mathrm{RGO}(24 \mathrm{~h}$ ), (which contain the same amount of immobilized enzyme, $40 \mathrm{mg} / \mathrm{g}$ ) was compared, the catalytic activity of $\mathrm{Ngsa} / \mathrm{GO}(3 \mathrm{~h})$ was considerably superior (73.6 \% conversion) than $\mathrm{Ngsa} / \mathrm{RGO}(24 \mathrm{~h})$ (only $24 \%$ conversion). This behavior can be attributed to the lower hydrophilic character of RGO which confers lower dispersability in the buffer than GO. In fact, it has been reported that good activity of naringinase immobilized on reduced graphene oxide can be only obtained when dispersability of the RGO in water is increased by using surfactants as additives. ${ }^{19}$

It appears then, that the combination of naringinase with the highly hydrophilic GO provides an excellent biocatalyst to produce naringenin and/or prunin without need of further additives.

\section{Effect of storage time in the stability of immobilized crude naringinase:}

The activity was tested after 0,10 and 20 days of storage. As can be in Figure S3 the catalytic activity was maintained after 20 days of storage, showing the high stability overtime of the enzyme supported on GO. 


\section{Conclusions}

Naringenin and prunin, two highly valuable citrus flavonoids, have been produced with excellent success through a sustanainable and green process by enzymatic hydrolysis of naringin, a glycosylated flavonoid highly abundant in citrus wastes. For that, crude Naringinase from Penicillium decumbens has been purified by a simple method obtaining a purified enzyme with high $\alpha$-rhamnosidase activity. Both, crude and purified enzymes have been covalently immobilized on graphene oxide. It has been showed that both immobilized enzymes were less affected by the reaction temperature and showed increased thermal stability with respect the free naringinase. The pure and crude GO supported enzymes showed higher affinity for the substrate than the free enzymes, high activity recovery, long-term stability and high production capacity. The biocatalyst designed here has a high potential for a more sustainable and greener large-scale production of citrus flavonoids such as naringenin and prunin, by enzymatic hydrolysis of naringin. This procedure clearly overcomes hydrolysis methods with mineral acids ${ }^{42}$ as well as synthetic methods reported ${ }^{43}$ in where several steps are required and lower selectivity is achieved.

\section{Experimental Section}

\section{$\underline{\text { Reactants }}$}

Naringinase, naringin, prunin, naringenin, $p$-nitrophenyl- $\alpha$-L-rhamnopyranoside (RhapNP), p-nitrophenyl- $\beta$-D-glucoside (Glc-pNP), potassium sodium tartrate tetrahydrate, alpha-D-Glucose, L-Rhamnose monohydrate, D-(-)-Fructose, Bicinchoninic acid kit for protein determination, graphite $<20 \mu \mathrm{m}$ and 3,5-Dinitrosalicylic acid were purchased from Sigma-Aldrich and DEAE-Sephacel from Pharmacia, Sweden. 


\section{Catalysts preparation and characterization}

\section{Synthesis Graphene oxide (GO)}

GO was prepared from graphite by a modified Hummer's method. ${ }^{44}$ Typically, concentrated $\mathrm{H}_{2} \mathrm{SO}_{4}(360 \mathrm{~mL})$ was added to a mixture of graphite $(7.5 \mathrm{~g})$ and $\mathrm{NaNO}_{3}$ $(7.5 \mathrm{~g})$, and the mixture was cooled down to $0{ }^{\circ} \mathrm{C}$ in an ice bath. $\mathrm{KMnO}_{4}(45 \mathrm{~g})$ was added slowly in small doses to keep the reaction temperature below $20{ }^{\circ} \mathrm{C}$. The solution was heated to $35{ }^{\circ} \mathrm{C}$ and stirred for $3 \mathrm{~h}$. Then $3 \% \mathrm{H}_{2} \mathrm{O}_{2}(1.5 \mathrm{~L})$ was slowly added. The reaction mixture was stirred for $30 \mathrm{~min}$ and, finally, the mixture was centrifuged (3700 rpm for $30 \mathrm{~min}$ ). After removing the supernatant, the remaining solid material was washed with $600 \mathrm{~mL}$ of water and centrifuged again, this process being repeated until the $\mathrm{pH}$ was neutral.

\section{Synthesis of Reduced Graphene oxide (RGO):}

$100 \mathrm{mg}$ of GO were added to quartz tubular vertical reactor, the reduction of this material was done with $5{ }^{\circ} \mathrm{C} / \mathrm{min}$ to $400{ }^{\circ} \mathrm{C}$ (holding 15 minutes) under $\mathrm{N}_{2}$. After the reduction cycle the material was keep under nitrogen atmosphere at room temperature for $90 \mathrm{~min}$. The resultant material was characterized by FTIR and elemental analysis.

\section{Immobilization of crude Naringinase on GO}

The immobilization of the enzyme (crude and pure) on GO was performed as follows: $50 \mathrm{mg}$ of $\mathrm{GO}$ dispersed in $3 \mathrm{~mL}$ of phosphate buffer solution (PBS) $\mathrm{pH}=7$ (100 mM) was submitted to ultrasound for 5 o 10 minutes, subsequently $3 \mathrm{mg}$ of each enzyme (1 $\mathrm{mg} / \mathrm{mL}$ ) was added and left in a closed flask under gentle agitation for 24 hours using a 
roller bottle. After that, the enzyme derivative was recovered by centrifugation, washed thoroughly with $100 \mathrm{mM}$ phosphate buffer $\mathrm{pH}=7$ and stored at $4{ }^{\circ} \mathrm{C}$ until used.

To determine the yield of immobilization, different aliquots of the supernatant were analysed by the bicinchoninic acid protein test. Typically, bicinchoninic acid test solution $\left(2 \mathrm{~mL}\right.$ ) was added to $0.1 \mathrm{~mL}$ sample and incubated at $37^{\circ} \mathrm{C}$ for $30 \mathrm{~min}$. After that, the optical density of the supernatant was determined spectrophotometrically at $\lambda_{562 \mathrm{~nm}}$

Infrared analyisis were recorded with a IR Vertex Burker DTGS (Detector), and a conventional quartz infrared cell Quartz KR55 windows connected to a vacuum dosing system, the sample were pressed into self-supporting pellets and treated under vacuum $\left(10^{-4}\right.$ to $\left.10^{-5} \mathrm{~Pa}\right)$ at $80^{\circ} \mathrm{C}$ for $45 \mathrm{~min}$.

Atomic force microscopy (AFM) images were taken on a MultiMode Nanoscope VIII scanning probe microscopy system (Veeco) under tapping mode. The protein were immobilized over GO as was describe before. The samples for AFM were prepared by dropping an aqueous suspension $\sim 0,04 \mathrm{mg} / \mathrm{mL}$ of support over freshly cleaved mica surface, the solvent was allowed to evaporate before measurement.

Transmission electron microscopy (TEM) micrographs were collected using a JEOL $2100 \mathrm{~F}$ microscope operating at $200 \mathrm{kV}$. Samples for transmission electronic microscope (TEM) were ultrasonically dispersed in $\mathrm{MQ}$ water, and transferred to carbon coated copper grids. 
The elemental analysis was performed in a Euro EA3000 Elemental Analyzer (EuroVector), using sulfanilamide as reference. The zeta potential of the supports was measured by analyzing 5 ppm of GO and RGO dispersed in PBS (pH 7100 mM) using the Zetasizer Nano ZS (Malvern Instruments Ltd., GB). Before zeta potential measurements, the samples were sonicated for 5 minutes. Zetasizer Nano ZS uses Laser Doppler Velocimetry to determine electrophoretic mobility. The zeta potential was obtained from the electrophoretic mobility by the Smoluchowski equation, that was $-8.96 \mathrm{mV}$ and $-7.89 \mathrm{mV}$ for $\mathrm{GO}$ and $\mathrm{RGO}$ respectively.

\section{Partial purification of naringinasa}

First, the chromatographic resin DEAE-Sephacel (5 g) was equilibrated with sodium phosphate buffer $\left(\mathrm{NaH}_{2} \mathrm{PO}_{4} / \mathrm{Na}_{2} \mathrm{HPO}_{4}\right) 5 \mathrm{mM}(\mathrm{pH}$ 6.8). Then, $500 \mathrm{mg}$ of crude Naringinase from Penicillium decubens were diluted in $50 \mathrm{~mL}$ water milliQ, and dialysed for $24 \mathrm{~h}$ at $5{ }^{\circ} \mathrm{C}$. The solution of naringinase was added to the ion exchange resin and maintained under gentle stirring for 1 hour. The adsorption of the enzyme was monitored by bicinchoninic acid protein test, until the enzyme was not detected in the solution. ${ }^{37}$ The resin was separated from the solution by filtration and naringinase was desorbed using a $\mathrm{NaCl}$ gradient of increasing concentration $(25-1000 \mathrm{mM}, \mathrm{V}=50$ $\mathrm{mL}$ ). After dialysis, performed to remove the salt, this partially purified enzyme solution was used to study the activity over specific substrates. Typically, an aliquot of each enzyme solution $(50 \mu \mathrm{L})$ was added to $0.7 \mathrm{~mL}$ sodium citrate buffer $50 \mathrm{mM}\left(50{ }^{\circ} \mathrm{C}\right.$; $\mathrm{pH}$ 4.5) containing $50 \mu \mathrm{L}$ Rha-pNP (p-nitrophenyl-alpha-L-rhamnopyranoside) or GlcpNP (p-nitrophenyl- $\beta$-D-glucoside) $0.5 \mathrm{mM}$. After 5 minutes, $0.8 \mathrm{~mL}$ of $\mathrm{Na}_{2} \mathrm{CO}_{3}(1 \mathrm{M})$ was added to stop the reaction and the absorbance was measured at $405 \mathrm{~nm}$ using a 
UV-Vis Spectrometer. Furthermore, the hydrolysis activity of these enzyme solutions was studied using naringin as substrate. An aliquot of each enzyme solution (50 $\mu \mathrm{L})$ were added to $200 \mu \mathrm{L}$ of naringin $8.6 \mathrm{mM}\left(50{ }^{\circ} \mathrm{C} ; \mathrm{pH} 4.5\right)$ under gently stirring for 10 minutes of reaction, then $250 \mu \mathrm{L}$ of DNS solution were added to the mixture, and the conversion were measured using the DNS method. ${ }^{45}$ The enzyme solutions were lyophilized and used for the immobilization assays on GO.

\section{Polyacrylamide gel electrophoresis}

The soluble enzyme was analyzed using SDS-PAGE (10\%) according to Laemmli. ${ }^{46}$ The molecular weight standard (GE Healthcare Life Sciences, Uppsala, Sweden) consisted of phosphorylase B (97 kDa), bovine serum albumin (66 kDa), ovalbumin (45 kDa), carbonic anhydrase carbonic (30 kDa), trypsin inhibitor (20.1 kDa) and $\alpha$-lactalbumin (14.4 kDa). The gels were stained with silver, according to Heukeshoven and Dernick. ${ }^{47}$

\section{Catalytic experiments}

\section{Determination of the enzyme activities}

Typically, an aliquot of the enzyme $(50 \mu \mathrm{L})(1 \mathrm{mg} / \mathrm{mL})$ was added to $0.7 \mathrm{~mL}$ sodium citrate buffer $50 \mathrm{mM}\left(50^{\circ} \mathrm{C}\right.$; $\left.\mathrm{pH} 4.5\right)$ containing $50 \mu \mathrm{L}$ Rha-pNP (p-nitrophenyl-alpha-Lrhamnopyranoside) or Glc-pNP (p-nitrophenyl- $\beta$-D-glucoside) $0.5 \mathrm{mM}$. After 5 minutes, $0.8 \mathrm{~mL}$ of $\mathrm{Na}_{2} \mathrm{CO}_{3}(1 \mathrm{M})$ was added to stop the reaction and the absorbance was measured at $405 \mathrm{~nm}$ using UV-Vis Spectrometer (Varian Cary 50 conc UV-Vis Spetrophotometer). One enzyme unit (U) was considered the amount of enzyme required to liberate $1 \mu \mathrm{mol}$ of $\mathrm{p}$-nitrophenol per minute under the described reaction 
conditions. The quantification of $p$-nitrophenol $\left(\varepsilon_{405 \mathrm{~nm}}=17.791 \mathrm{mM}^{-1} \cdot \mathrm{cm}^{-1}\right)$ was determined as described by Romero. ${ }^{41}$

\section{Determination of Michaelis-Menten constant $\left(\mathrm{K}_{\mathrm{M}}\right)$}

The kinetic parameters for crude and purified enzyme in free and immobilized forms were determined by measuring the reaction rates (under the conditions above mentioned) at substrate concentrations of Rha-pNP ranging from $0.006-0.312 \mathrm{mM}$ while keeping the reaction time constant $(10 \mathrm{~min})$. The Michaelis constants $\left(\mathrm{K}_{M}\right)$ were determined by the Lineweaver-Burk plots.

\section{Determination of catalytic activity in function of $\mathrm{pH}$ and temperature.}

The effect of $\mathrm{pH}$ on the catalytic activity of the crude and pure enzymes in free and immobilized form were determined by incubating the enzyme in the presence of the substrate (Rha-pNP) in a universal buffer (Mcllvaine) of $\mathrm{pH}$ varying from 3.0 to 8.0. Measurements of activities were carried out at different values of $\mathrm{pH}$ of incubation under the conditions described above.

The optimum temperature for hydrolysis of Rha-pNP was determined by measuring the enzyme activity (crude and pure) in free and immobilized form, at different temperatures varying between $25{ }^{\circ} \mathrm{C}$ and $100{ }^{\circ} \mathrm{C}$ under the same experimental conditions as described before.

\section{Thermal stability of the enzyme}

The thermal stability of the enzyme was determined by heating the pure and crude enzyme in free and immobilized form at temperatures between 30 and $100{ }^{\circ} \mathrm{C}$ in a buffer solution ( $\mathrm{pH} 4.5)$ of sodium citrate $(50 \mathrm{mM})$ during one hour. Subsequently the 
substrate Rha-pNP was added and the enzyme activity was determined as indicated above.

\section{Production of prunin and naringenin and study of biocatalysts stability}

Naringinase activities were determined by incubating the enzyme ( $3 \mathrm{mg}$ of enzyme on GO (50 mg) (1 mg protein/mL) with $8.6 \mathrm{mM}$ of the substrate naringin, in $3 \mathrm{~mL} 50 \mathrm{mM}$ citrate buffer $\left(\mathrm{pH} \mathrm{4.5)}\right.$ at $50{ }^{\circ} \mathrm{C}$ for 30 minutes. After one cycle of reaction, the mixture was centrifuged at $6000 \mathrm{rpm}$ during $10 \mathrm{~min}$, the biocatalyst was removed and washed, and used in a subsequent reaction cycle. The analysis of products was performed by HPLC (Shimadzu LC-20ADXR). The amounts of naringin, prunin and naringenin have been estimated using Diode Array Detector SPD-M20 A, with the column Mediterranean SEA $185 \mu \mathrm{m} 25 \times 0.46$ in a gradient mode (Table S5) using water and acetonitrile as mobile phase at flow $0.8 \mathrm{~mL} / \mathrm{min}$. The standards for flavonoids were diluted in ethanol and filtered with filters of Nylon $(0.22 \mu \mathrm{m})$, the absolute calibration curves of naringin, prunin and naringenin were done from 0 to $1 \mathrm{mM}$ at $\lambda=280 \mathrm{~nm}$. The sugars released in the reaction (glucose and rhamnose) were determined using the Refractive Index Detector RID-20A, with a column (ICE-COREGEL 87H3), in isocratic mode using $\mathrm{H}_{2} \mathrm{SO}_{4} 4 \mathrm{mM}$ as mobile phase, at a flow $0.6 \mathrm{~mL} / \mathrm{min}$ using the column's oven is CTO-20 Ac at $75{ }^{\circ} \mathrm{C}$. Fructose was used as internal standard for sugar determination, and the samples were filtered with filters of Nylon $(0.22 \mu \mathrm{m})$, the calibration curves of pure sugars samples glucose and rhamnose were done from 0 to $10 \mathrm{mM}$. The combination of the two methods allows us to determinate all the different products generated during the hydrolysis of naringin. The sugars were also determined by dinitrosalicylic acid method (DNS). ${ }^{45}$ 


\section{Activity recovery calculation}

Activity recovery was determined according to ${ }^{48}$ for that Naringin, $8.6 \mathrm{mM}$ in $12 \mathrm{~mL}$ of citrate buffer at $\mathrm{pH} 4.5(50 \mathrm{mM})$ was submitted to hydrolysis using $3 \mathrm{mg}$ of free naringinase (pure and crude). The activity was measured and expressed as sugars released $(\mu \mathrm{mol}) \cdot \mathrm{min}^{-1}$. Then, $3 \mathrm{mg}$ of naringinase were put in contact with $50 \mathrm{mg}$ of GO during 24. After that the solid was recovered by filtration and the activity of the total amount of immobilized enzyme was determined under the same conditions as the free enzyme.

Activity recovery is expressed as a percentage as: (activity of immobilized enzyme/activity of free enzyme) x 100

Catalytic stability of the immobilized naringinase with time of storage: To estimate the stability, the activity of the immobilized crude naringinase was tested using naringin as substrate after 0,10 and 20 days of storage. After each test, the biocatalyst was washed and was keep at $4{ }^{\circ} \mathrm{C}$ until the new use. The catalytic activity was determined by Dinitrosalicylic acid method (DNS).

\section{Conflicts of interest}

There are no conflicts to declare.

\section{Acknowledgments}

Authors acknowledge financial support from MICINN Project CTQ-2015-67592-P, and Program Severo Ochoa (SEV-2016-0683). JVC thanks to Universitat Politécnica de Valencia for predoctoral fellowships. JY and AC thank the support from the National 
Natural Science Foundation of China (Grant No. 21320102001) and the 111 Project (Grant No. B17020).

\section{References}

1 J. Zhang, Proc. Fla. State Hort. Soc., 2007, 120, 288.

2 K. Sudto, S. Pornpakakul and S. Wanichwecharungruang, Int. J. Food Sci. Technol., 2009, 44, 1737.

3 M. Roitner, T. Schalkhammer and F. Pittner, Appl. Biochem. Biotechnol., 1984, 9, 483.

4 I. A. Ribeiro, J. Rocha, B. Sepodes, H. Mota-Filipe and M. H. Ribeiro, J. Mol. Catal. B Enzym., 2008, 52, 13.

5 M. Puri and U. C. Banerjee, Biotechnol. Adv., 2000, 18, 207.

6 H. Vila-Real, A. J. Alfaia, M. E. Rosa, A. R. Calado and M. H. L. Ribeiro, Process Biochem., 2010, 45, 841.

7 J. Thirkettle, J. Antibiot. (Tokyo)., 2000, 53, 733.

8 C. Grassin and P. Fauquembergue, in Industrial Enzymology, ed. W.

S. Godfrey T, Nature Publishing Group, New York, 2nd editio., 1996, p. 225.

9 M. Ono, T. Tosa and I. Chibata, Agric. Biol. Chem., 1978, 42, 1847.

10 H. Y. Tsen and S. Y. Tsai, J. Ferment. Technol., 1988, 66, 193.

11 N. F. F. Soares and J. H. Hotchkiss, J. Food Sci., 1998, 63, 61.

12 M. Puri, H. Kaur and J. F. Kennedy, J. Chem. Technol. Biotechnol., 2005, 80, 1160.

13 S. Lei, Y. Xu, G. Fan, M. Xiao and S. Pan, Appl. Surf. Sci., 2011, 257, 
4096.

14 M. A. P. Nunes, H. Vila-Real, P. C. B. Fernandes and M. H. L. Ribeiro, Appl. Biochem. Biotechnol., 2010, 160, 2129.

15 M. D. Busto, V. Meza, N. Ortega and M. Perez-Mateos, Food Chem., 2007, 104, 1177.

16 M. Puri, S. S. Marwaha and R. M. Kothari, Enzyme Microb. Technol., 1996, 18, 281.

17 D. Norouzian, A. Hosseinzadeh, D. N. Inanlou and N. Moazami, World J. Microbiol. Biotechnol., 1999, 15, 501.

18 U. Ghosh \& H. Gangopadhyay, Indian J. Chem. Technol., 2003, 10, 701.

19 A. Gong, C. T. Zhu, Y. Xu, F. Q. Wang, D. K. Tsabing, F. A. Wu and J. Wang, Sci. Rep., 2017, 7, 1.

20 Y. Zhang, C. Wu, S. Guo and J. Zhang, Nanotechnol. Rev., 2013, 2, 27.

21 S. Hermanová, M. Zarevúcká, D. Bouša, M. Pumera and Z. Sofer, Nanoscale, 2015, 7, 5852.

22 M. Mathesh, B. Luan, T. O. Akanbi, J. K. Weber, J. Liu, C. J. Barrow, R. Zhou and W. Yang, ACS Catal., 2016, 6, 4760.

23 W. Li, H. Wen, Q. Shi and G. Zheng, Process Biochem., 2016, 51, 270.

24 S. G. Hong, J. H. Kim, R. E. Kim, S. J. Kwon, D. W. Kim, H. T. Jung, J. S. Dordick and J. Kim, Biotechnol. Bioprocess Eng., 2016, 21, 573.

25 F. Liu, Y. Piao, K. S. Choi and T. S. Seo, Carbon N. Y., 2012, 50, 123.

26 Z. Wang, X. Zhou, J. Zhang, F. Boey and H. Zhang, J. Phys. Chem. C, 2009, 113, 14071.

27 R. K. Singh, R. Kumar and D. P. Singh, RSC Adv., 2016, 6, 64993.

28 H. Vila-Real, A. J. Alfaia, M. R. Bronze, A. R. T. Calado and M. H. L. Ribeiro, Enzyme Res., 2011, 2011, 1. 
29 D. Mamma, E. Kalogeris, D. G. Hatzinikolaou, A. Lekanidou, D. Kekos, B. J. Macris and P. Christakopoulos, Food Biotechnol., 2004, 18, 1.

30 H. Y. Chang, Y. B. Lee, H. A. Bae, J. Y. Huh, S. H. Nam, H. S. Sohn, H. J. Lee and S. B. Lee, Food Chem., 2011, 124, 234.

31 S. Yadav, S. Yadava and K. D. S. Yadav, Process Biochem., 2013, 48, 1348.

32 Y. Zhu, H. Jia, M. Xi, L. Xu, S. Wu and X. Li, Food Chem., 2017, 214, 39.

33 T. Zhang, W. Yuan, M. Li, M. Miao and W. Mu, Food Chem., 2018, 269, 63.

34 Y. Zhu, H. Jia, M. Xi, J. Li, L. Yang and X. Li, Process Biochem., 2017, 62, 114.

35 D. Gerstorferová, B. Fliedrová, P. Halada, P. Marhol, V. Kren and L. Weignerová, Process Biochem., 2012, 47, 828.

36 H. Vila-Real, A. J. Alfaia, J. N. Rosa, P. M. P. Gois, M. E. Rosa, A. R. T. Calado and M. H. Ribeiro, J. Biotechnol., 2011, 152, 147.

37 P. K. Smith, R. I. Krohn, G. T. Hermanson, A. K. Mallia, F. H. Gartner, M. D. Provenzano, E. K. Fujimoto, N. M. Goeke, B. J. Olson and D. C. Klenk, Anal. Biochem., 1985, 150, 76.

38 H. P. Erickson, Biol. Proced. Online, 2009, 11, 32.

39 J. Zhang, F. Zhang, H. Yang, X. Huang, H. Liu, J. Zhang and S. Guo, Langmuir Lett., 2010, 26, 6083.

40 A. Marolewski, J. Med. Chem., 1996, 39, 1010.

41 C. Romero, A. Manjón, J. Bastida and J. L. Iborra, Anal. Biochem., 1985, 149, 566.

42 D. W. Fox and L. Savage, J. Am. Chem. Soc., 1952, 75, 2504.

43 R. Bognar, A. L. Tokes and H. Frenzel, Acta chim, 1969, 61(1), 79.

44 W. S. Hummers and R. E. Offeman, J. Am. Chem. Soc., 1958, 80, 
1339.

45 G. L. Miller, Anal. Chem., 1959, 31, 426.

46 U. K. Laemmli, Nature, 1970, 227, 680.

47 J. Heukeshoven and R. Dernick, Electrophoresis, 1985, 6, 103.

48 R. A. Sheldon and S. van Pelt, Chem. Soc. Rev., 2013, 42, 6223.

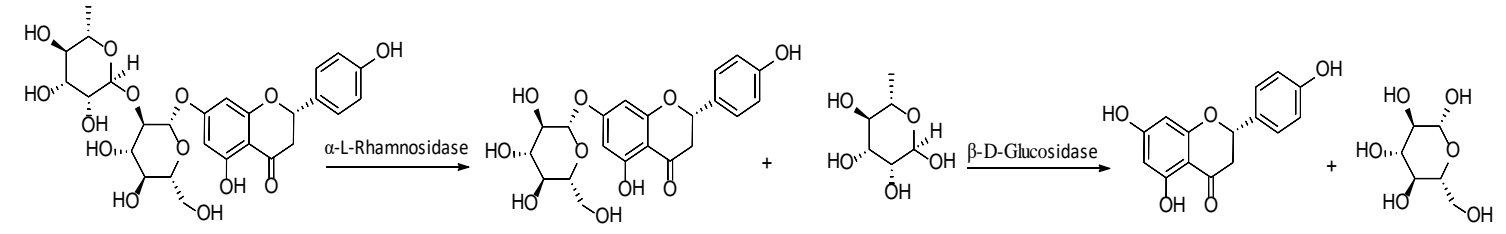

Scheme 1. Two step hydrolysis of Naringin 


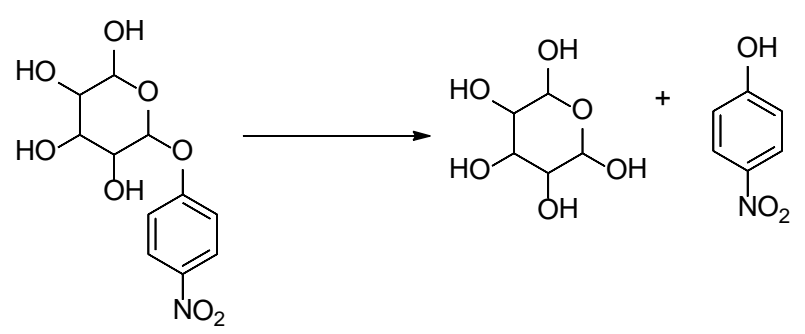

Scheme 2. a) Hydrolysis of p-nitrophenyl-alpha-L-rhamnopyranoside (Rha-pNP) 


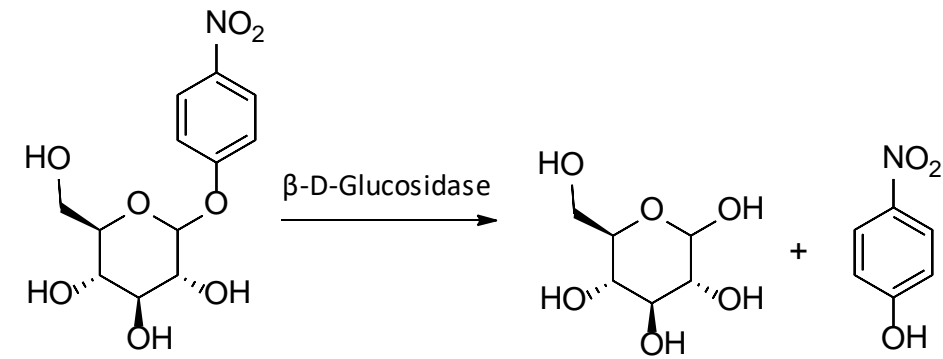

Scheme 2. b) Hydrolysis of p-nitrophenyl- $\beta$-D-glucoside (Glc-pNP) 


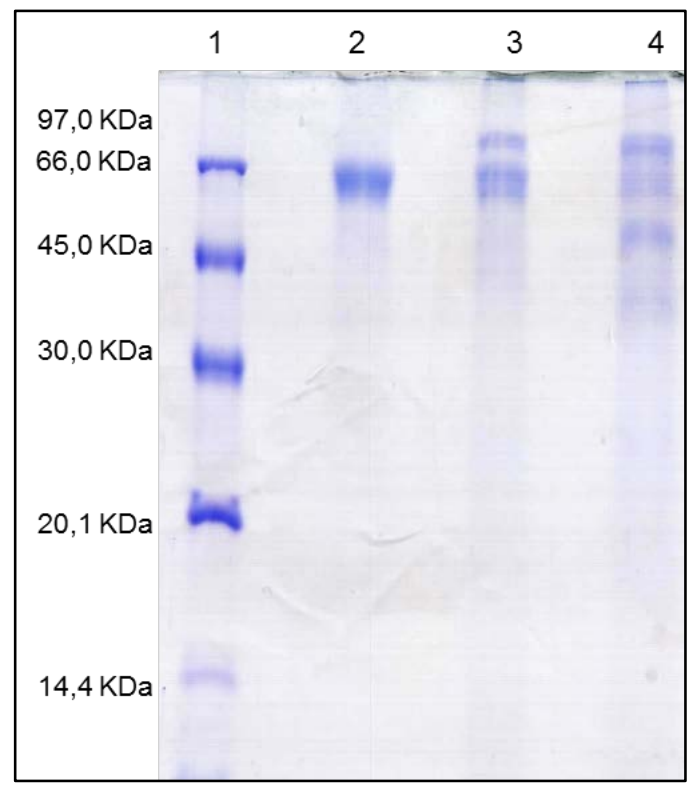

Figure 1. SDS-PAGE. Lane 1- Low molecular weight standards; Lane 2-Purified enzyme desorbed 50 mM; Lane 3- Enzyme desorbed 100 mM; Lane 4- Enzyme desorbed 150 $\mathrm{mM}$ 


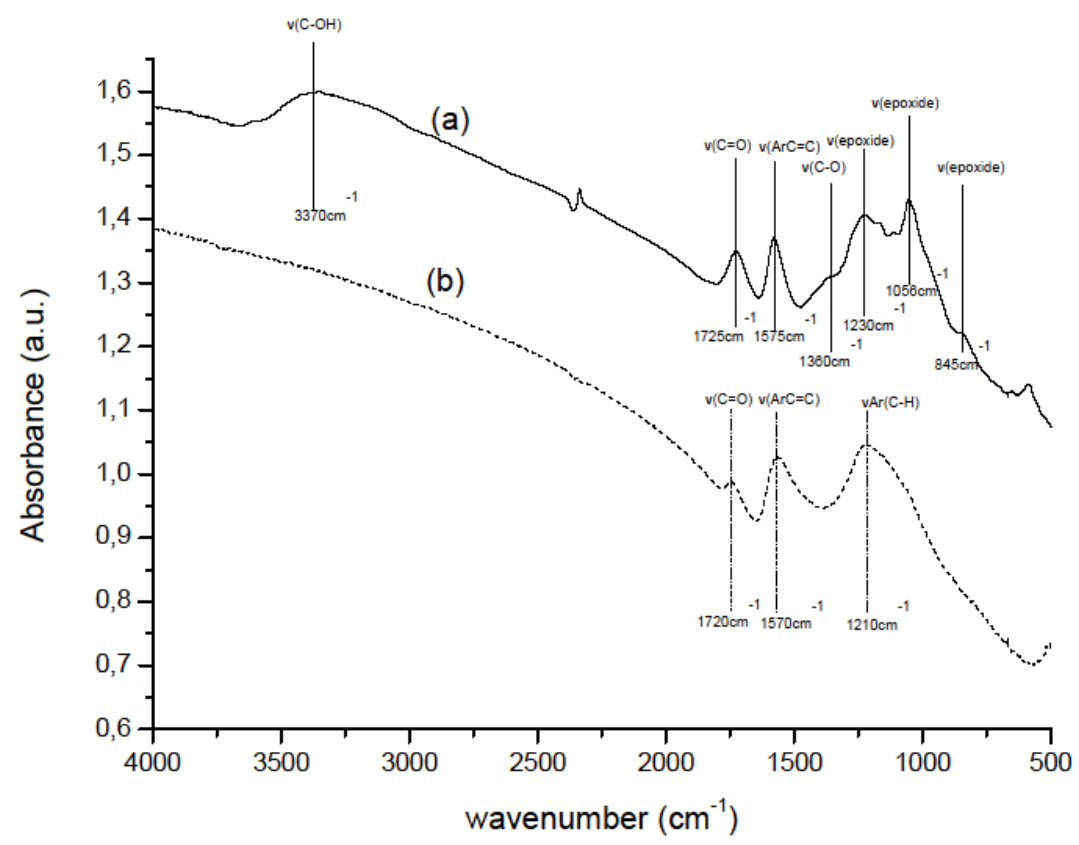

Figure 2. FTIR of GO(a) and RGO (b) at $80^{\circ} \mathrm{C}$ 


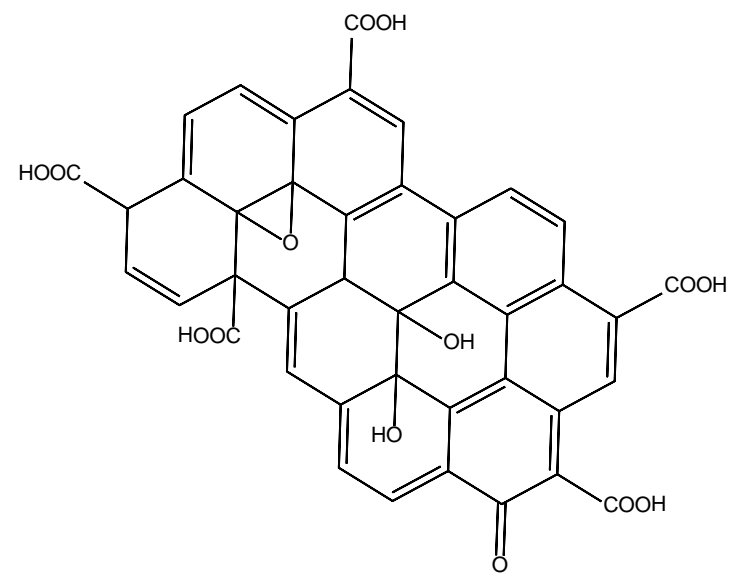

Figure 3. Schematic model of GO 

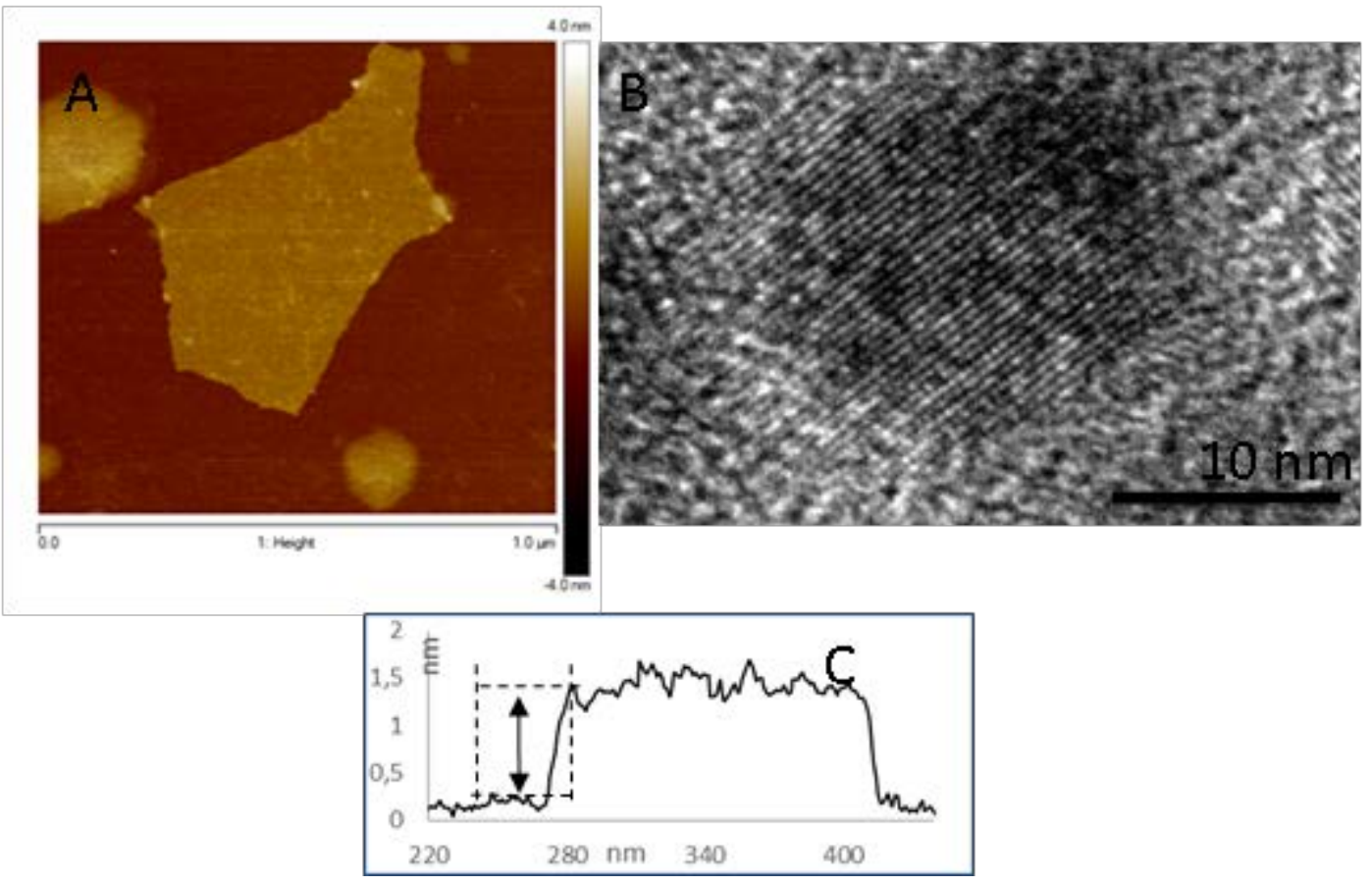

Figure 4. A) AFM image of GO; B) TEM image of GO; C) Height of AFM image 

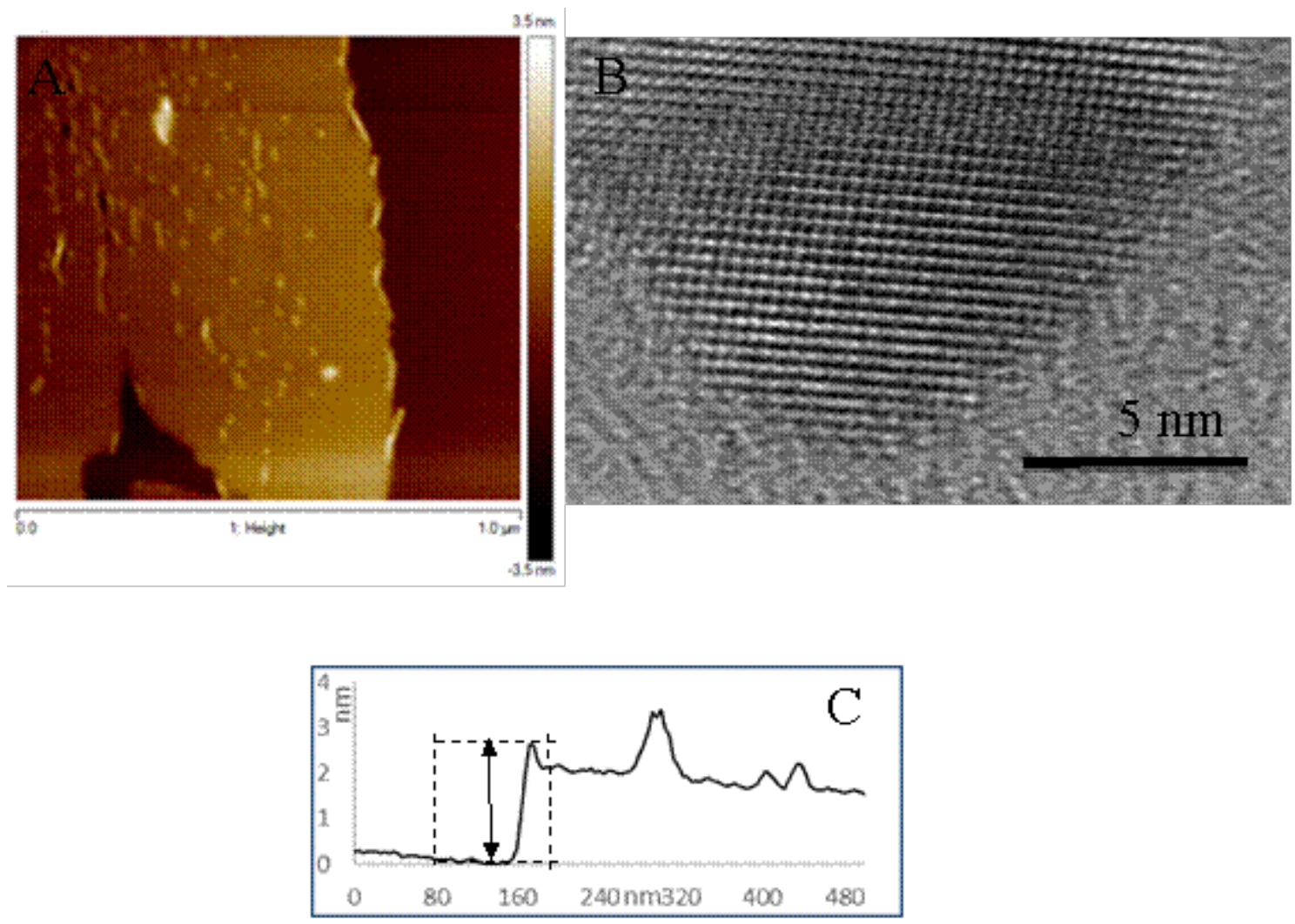

Figure 5. A) AFM image of Ngs/GO B) TEM image of Ngs/GO C) Height of AFM image 


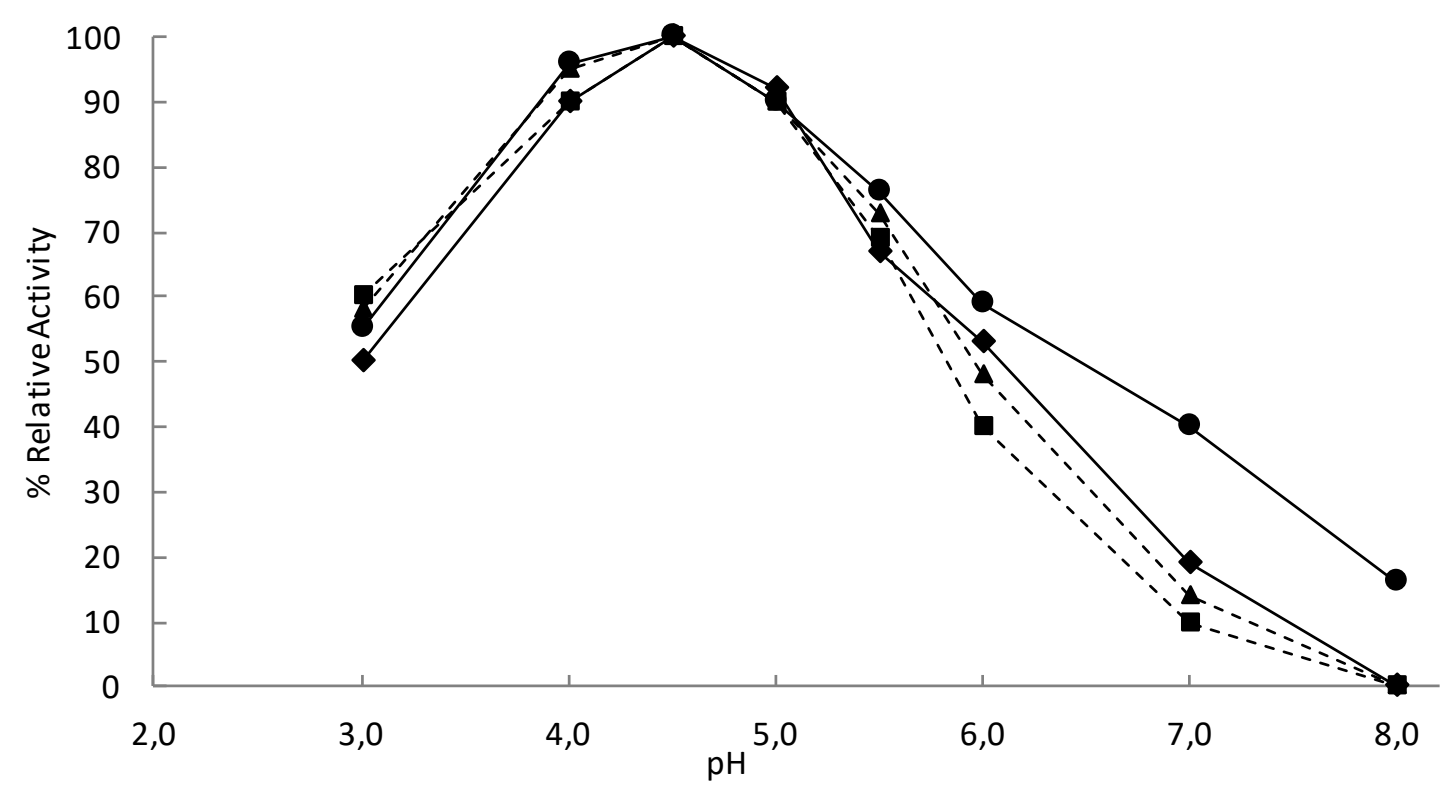

Figure 6. Relative activity in function of $\mathrm{pH}$ for free and immobilized naringinase $(-\bullet-)$ GO-Crude, $(-\bullet-)$ Free-Crude, $(---\Delta--)$ GO-Pure and (--- ---$)$ Free-Pure 


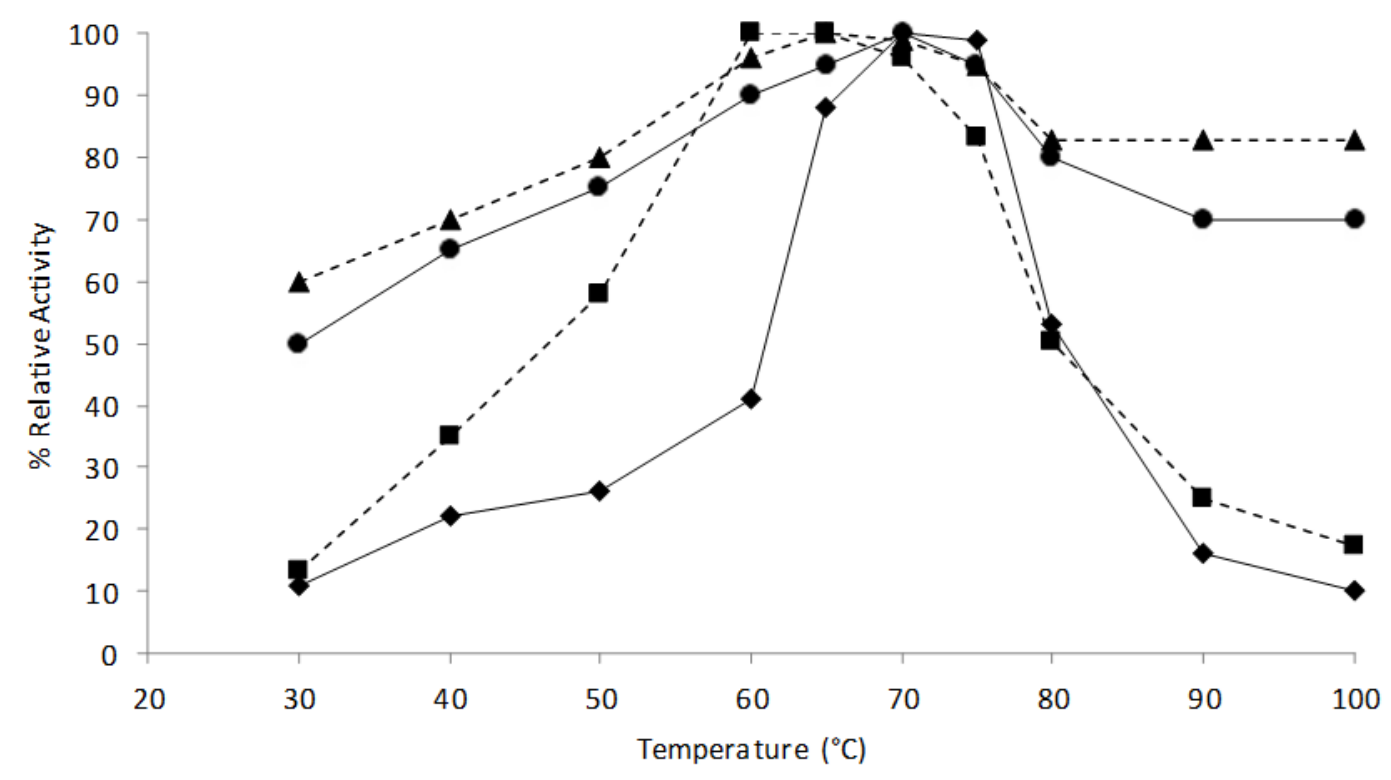

Figure 7. Influence of temperature on activity of free and immobilized naringinase

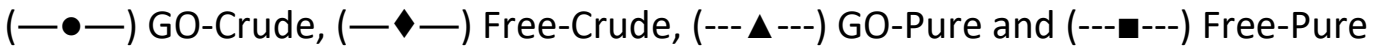




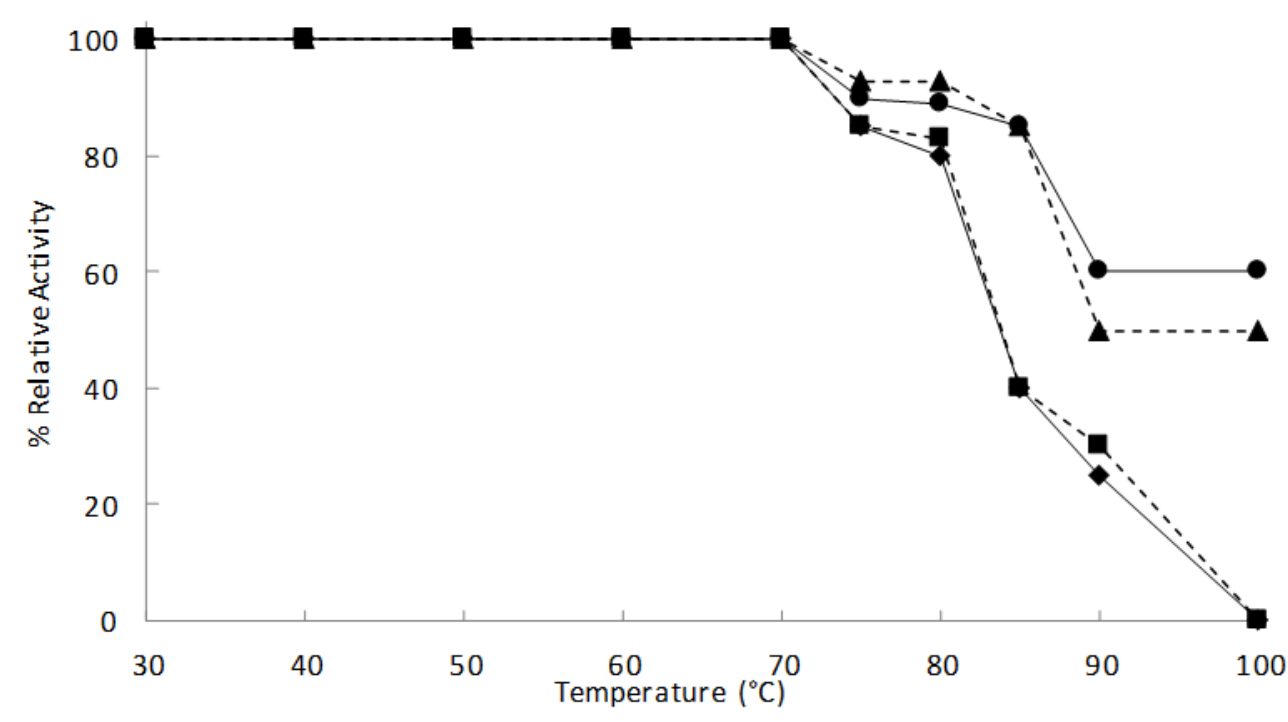

Figure 8. Thermal stability of free and immobilized naringinase (- - ) GO-Crude, $(-\downarrow-)$ Free-Crude, (--- $\Delta---)$ GO-Pure and (---ח---) Free-Pure 


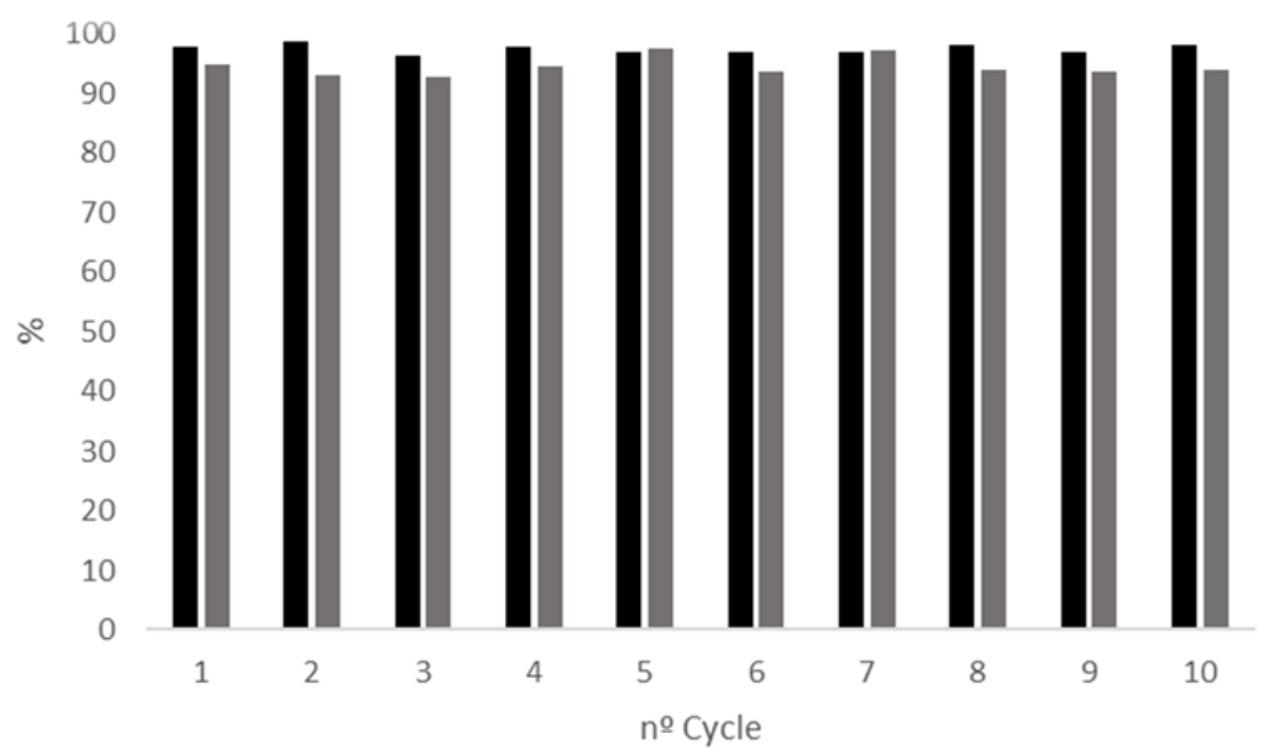

Figure 9. Reuse capacity of immobilized pure naringinase $(8.6 \mathrm{mM}$ naringin, Ngsapure/GO in $3 \mathrm{~mL}, 50 \mathrm{mM}$ citrate buffer (pH 4.5) at $50{ }^{\circ} \mathrm{C}$ for 30 minutes). (Conversion, $\backsim$ Selectivity Prunin) 


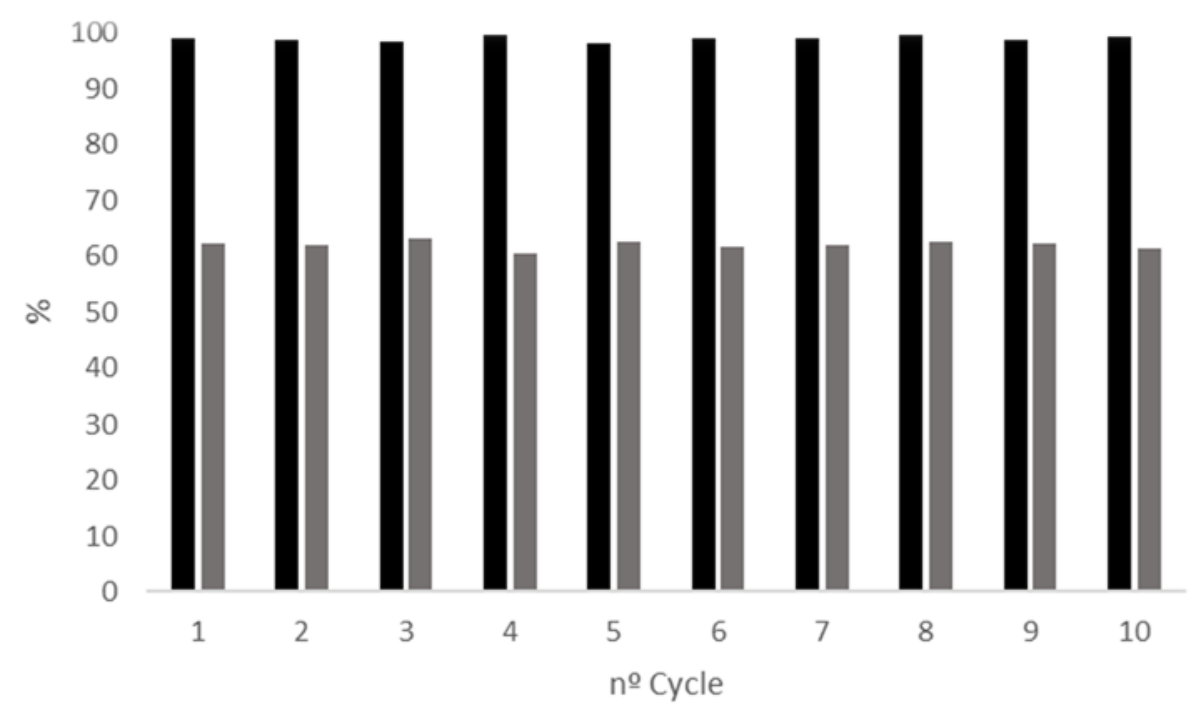

Figure 10. Reuse capacity of immobilized crude naringinase $(8.6 \mathrm{mM}$ naringin, Ngsacrude/GO in $3 \mathrm{~mL}, 50 \mathrm{mM}$ citrate buffer ( $\mathrm{pH} \mathrm{4.5)}$ at $50^{\circ} \mathrm{C}$ for 30 minutes). (Conversion, -Selectivity Naringenin ) 


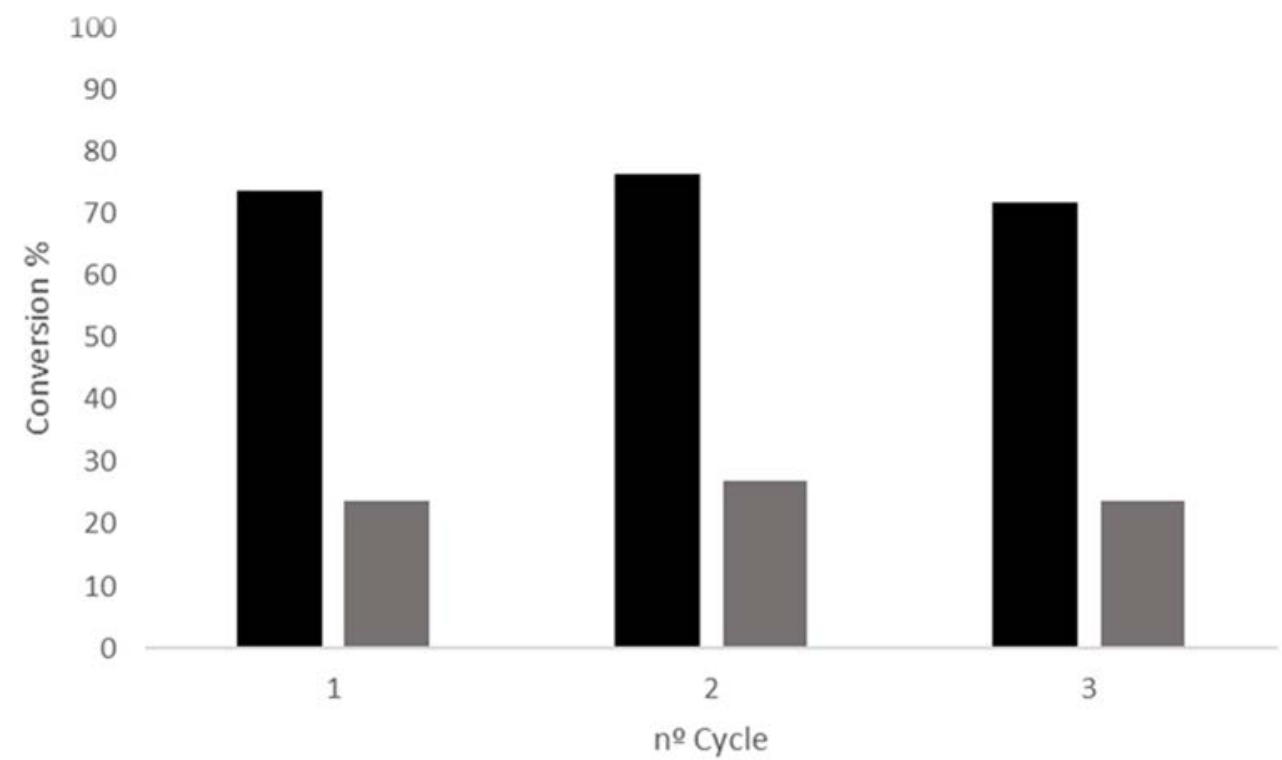

Figure 11. Conversion of naringin obtained using Ngsa/GO (3 h) and Ngsa/RGO(24 h) during three consecutive runs. Conversion was determined by DNS analysis. ( $\square \mathrm{GO}-3 \mathrm{~h}$, RGO-24 h) 
Table 1. Rhamnosidase and Glucosidase activities of the crude and purified naringinase

\begin{tabular}{lccc}
\hline & Protein $(\mathrm{mg} / \mathrm{mL})$ & $\begin{array}{c}\text { Rhamnosidase } \\
\text { Activity }(\mathrm{mU} / \mathrm{mg})^{*}\end{array}$ & $\begin{array}{c}\text { Glucosidase } \\
\text { Activity }(\mathrm{mU} / \mathrm{mg})^{*}\end{array}$ \\
\hline Crude enzyme & 0.181 & 237.10 & 263.63 \\
Dialyzed enzyme & 0.196 & 224.37 & 245.20 \\
DEAE-Sephacel & 0.098 & 422.32 & 47.53 \\
\hline
\end{tabular}

${ }^{*} m U$ : milliunities 
Table 2. $K_{M}$ reported values of free and immobilized naringinase

\begin{tabular}{|c|c|c|c|c|c|}
\hline \multicolumn{6}{|c|}{$\mathrm{K}_{\mathrm{M}}(\mathrm{mM})$} \\
\hline Enzyme & Free & Immobilized & $\mathrm{CK}_{\mathrm{M}}$ & Support & Reference \\
\hline Naringinase Penicillum sp. & 3.60 & 2.10 & 1.71 & $\begin{array}{l}\text { Cellulose films } \\
\text { (CTA) }\end{array}$ & 11 \\
\hline $\begin{array}{c}\text { Naringinase Penicillum } \\
\text { decubens }\end{array}$ & 0.23 & 0.35 & 0.67 & $\begin{array}{l}\text { Polyvinyl alcohol } \\
\text { (PVA) }\end{array}$ & 14 \\
\hline Naringinase Penicillum sp. & 8.40 & 10.00 & 0.84 & $\begin{array}{l}\text { Calcium alginate } \\
\text { beads }\end{array}$ & 16 \\
\hline Naringinase Penicillum sp. & 5.00 & 2.00 & 2.50 & Wood chips & 12 \\
\hline Naringinase A.niger & 0.64 & 0.53 & 1.21 & Tannin-Cellulose & 9 \\
\hline $\begin{array}{l}\text { Naringinase Penicillum } \\
\text { decumbens }\end{array}$ & 1.87 & 0.80 & 2.33 & GO-crude Enzyme & This work \\
\hline $\begin{array}{c}\text { Naringinase Penicillum } \\
\text { decumbens }\end{array}$ & 1.80 & 0.61 & 2.95 & GO-pure Enzyme & This work \\
\hline
\end{tabular}

